\title{
A Semi-Selective Agar Medium to Detect the Presence of Xanthomonas axonopodis pv. malvacearum in Naturally Infected Cotton Seed
}

\author{
Yeshwant R. Mehta ${ }^{1}$, Cleide Bomfeti' ${ }^{2}$ \& Viviani Bolognini ${ }^{2}$ \\ ${ }^{1}$ Laboratório de Patologia de Sementes, Área de Proteção de Plantas, Instituto Agronômico do Paraná-IAPAR, \\ Cx. Postal 481, Londrina, PR, Brasil, e-mail: yrmehta@iapar.br; ${ }^{2}$ Bolsista FACUAL
}

(Accepted for publication on 23/06/2005)

Corresponding Author: Yeshwant R. Mehta

MEHTA, Y.R., BOMFETI, C. \& BOLOGNINI, V. A semi-selective agar medium to detect the presence of Xanthomonas axonopodis pv. malvacearum in naturally infected cotton seed. Fitopatologia Brasileira 30:489-496. 2005.

\begin{abstract}
A semi-selective agar medium was developed for detection of Xanthomonas axonopodis pv. malvacearum (Xam) in cotton (Gossypium hirsutum) seed. The basic medium was peptone-sucrose-agar (PSA). Criteria for the semi-selective medium were the typical colony characters of Xam and its pathogenicity on cotton. Several systemic fungicides and antibiotics in different concentrations were tested alone or in combination with others. The final composition of the semi-selective agar medium was established after several attempts in order to inhibit most of the fungal and bacterial saprophytes and favour the development of Xam. It contained PSA + cyclohexamide, cephalexin, pencycuron, triadimenol and tolylfluanid. The bacteria were recovered from naturally infected seeds by the direct plating of 2,000 surface disinfected seeds on the semi-selective medium. The recovery of the pathogen from naturally infected leaf tissues and in dilution plating, on semiselective medium and on nutrient agar, were comparable. Among the three detection methods tested, the semi-selective medium was found to be the most reliable and quantifiable. Degree of severity of angular leaf spot in the field was not always correlated with the level of infection in the seed. This is the first report of a semi-selective agar medium to detect the presence of Xam in naturally infected cotton seed.
\end{abstract}

Additional keywords: Gossypium hirsutum, black arm of cotton, angular leaf spot.

\section{RESUMO}

Meio semi-selectivo para detectar a presença de Xanthomonas axonopodis pv. malvacearum em sementes de algodoeiro naturalmente infetadas

Um meio de cultura semi-seletivo foi desenvolvido para detectar Xanthomonas axonopodis pv. malvacearum (Xam) em sementes do algodoeiro (Gossypium hirsutum). O meio básico foi peptona-sacarose-ágar (PSA). Os critérios para o meio semi-seletivo foram; as características típicas das colônias de Xam e sua patogenicidade em algodoeiro. Vários fungicidas sistêmicos e antibióticos foram testados sozinhos ou em combinação com outros em diferentes concentrações. A composição final do meio semi-seletivo foi estabelecida após várias tentativas no sentido de inibir a maioria dos fungos e bactérias saprofíticas e favorecer o desenvolvimento de Xam. O meio contém: PSA + ciclohexamida, cefalexina, pencycuron, triadimenol e tolylfluanid. A bactéria foi recuperada de sementes naturalmente infetadas através do plaqueamento direto de 2.000 sementes externamente desinfestadas em meio semi-seletivo. A recuperação do patógeno de tecidos homogenizados da folha infetada e a recuperação em plaqueamento por diluição, em meio semi-seletivo e em agar nutriente, foram comparáveis. Entre os três métodos de deteç̧ão, o meio semi-seletivo foi o mais preciso e confiável. O nível da severidade de infecção em campo não era sempre correlacionado com o nível de infecção nas sementes. Este é o primeiro relato de meio semi-seletivo para detectar a presença de Xam em sementes do algodoeiro.

Palavras-chave adicionais: Gossypium hirsutum, mancha angular.

\section{INTRODUCTION}

Angular leaf spot caused by Xanthomonas axonopodis pv. malvacearum (Xam) [Sin. X. campestris pv. malvacearum (Smith) Dye)] is one of the most important diseases of tetraploid cotton (Gossypium hirsutum L. and G. barbadense L.) in many countries, including Brazil. The disease can cause heavy yield losses depending on the year and the cultivar. Cotton seed is considered to be an important transmission vehicle of Xam and a source of primary inoculum (Bain, 1939; Brinkerhoff \& Hunter, 1963; Hunter \& Brinkerhoff, 1964; Mohan, 1983a, 1983b). Tarr (1961) and Brinkerhoff \& Hunter (1963) reported that internally infected seed between 0.017 and $2.0 \%$ resulted in severe losses in commercial cotton fields in Sudan and in the USA. So far, in Brazil, there is no regulation, either for field inspections for angular leaf spot or for laboratory testing, of seeds infected with the pathogen. As a result, the disease is on the increase in the States of Paraná, São Paulo, Goiás, and Mato Grosso, and severe epiphytotics of the disease 
occurred in 2001, 2002 and 2003 in these states. Currently, the Brazilian Ministry of Agriculture is considering the adoption of rules and regulations requiring field inspections for the presence of angular leaf spot disease. A zero tolerance for fields infested with the disease is being proposed. Any seed production field with the disease, irrespective of the level of infection, will be destined for commercial cotton and not for seed production. This stringent regulation may create seed shortages and other problems. The year 2003 was very favourable for angular leaf spot, and in the State of Mato Grosso, there was not a single field which was completely free from the disease. Thus, the success of a seed health certification program, as in other cases (Mohan \& Schaad, 1987), would depend on the availability of a reliable method to detect Xam in naturally infected seeds.

Several semi-selective agar media were reported for phytopathogenic bacteria like Corynebacterium spp. (Clavibacter), Erwinia spp., Pseudomonas spp. and Xanthomonas spp. (Kado \& Heskett, 1970), Xanthomonas translucens pv. undulosa (Schaad \& Forster, 1985), X. axonopodis pv. phaseoli (Clafin et al., 1987), and Pseudomonas syringae pv. syringae (Mohan \& Schaad, 1987). In Israel, a method to detect the pathogen in the seed lot, but not quantitatively, was reported by Halfon-Meiri \& Volcani (1977). A semi-selective medium to detect and to quantify the presence of Xam in cotton seed has not been reported. Because of the lack of an appropriate, sensitive, selective medium, research on control measures including methods to erradicate the bacteria from the seed is hampered. A preliminary report about semi-selective medium has been published (Mehta \& Bolognini, 2003). This paper describes a semi-selective agar medium and compares other methods to detect the presence and longevity of Xam in naturally infected cotton seed.

\section{MATERIALS AND METHODS}

\section{Development of semi-selective agar medium}

Some of the semi-selective media reported for xanthomonads (Schaad \& Forster, 1985; Claflin et al., 1987) were evaluated in preliminary tests. Some systemic fungicides were tested alone or in combination with others in different concentrations. Some of the antibiotics were also evaluated by paper disc method (Randhawa \& Schaad, 1984). The basic medium was peptone-sucrose-agar (PSA), containing 0.35 g Ca $\left(\mathrm{NO}_{3}\right), 0.35 \mathrm{~g} \mathrm{FeSO}_{4}, 1.4 \mathrm{~g} \mathrm{Na}_{2} \mathrm{HPO}_{4}, 3.5 \mathrm{~g}$ peptone, $14.0 \mathrm{~g}$ sucrose, $10.5 \mathrm{~g}$ bacto-agar, $700 \mathrm{ml}$ distilled water, $\mathrm{pH}$ 6.8. Criteria for the semi-selective medium were the typical colony characters of Xam and its pathogenicity on cotton. The final composition of the semi-selective agar medium was established so as to inhibit most of the fungal and bacterial saprophytes and to favour the isolation of Xam. It contained: PSA + cycloheximide (Sigma) $100 \mathrm{mg}$ (2 ml of a stock solution of $500 \mathrm{mg}$ in $10 \mathrm{ml}$ of $75 \%$ alcohol); cephalexin (Sigma) $10 \mathrm{mg}$ (1 ml of a stock solution of 100 $\mathrm{mg}$ in $10 \mathrm{ml}$ of $75 \%$ alcohol); pencycuron $0.05 \mathrm{~g}$ (Monceren
PM, Bayer S.A.); triadimenol $1 \mathrm{ml}$ (Baytan SC, Bayer S.A.); tolylfluanid (Euparen 500PM, Bayer S.A.) (1 ml of a stock solution of $0.125 \mathrm{~g}$ in $10 \mathrm{ml}$ of sterilized water). The fungicides pencycuron, triadimenol and tolylfluanid were efficient in inhibiting the development of most of the seedborne fungal saprophytes. Tolylfluanid as a seed dressing fungicide is also known to control Rhizoctonia solani Kühn in cotton seedlings (Goulart \& Ferraz, 2001). Antibiotics and fungicides were added, after the medium was autoclaved, in the order presented above. In all the tests, young culture of Xam was streaked onto two others containing PSA and two plates containing semi-selective medium and maintained as controls to ensure that in none of the tests Xam was inhibited by the semi-selective medium.

\section{Plating efficiency}

Plating efficiency was determined in comparison with Difco nutrient agar (NA) as a standard medium and was evaluated by colony counts at 10 fold serial dilutions $\left(10^{-4}\right.$ $10^{-5}, 10^{-6}, 10^{-7}$ ), using young cultures of 13 strains of Xanthomonas sp. in three replicates. Initial cell suspension was adjusted to an absorbance of 0.1 at $640 \mathrm{~nm}$ using a spectrophotometer. One hundred microlite of each diluted suspension was distributed on each Petri dish containing either NA or semi-selective medium. Dilutions yielding over 300 colonies per plate were not considered for counting. The mean percentage of recovery of the colony forming units (cfu) were compared with NA. The percentage of plating efficiency was calculated in relation to the cfu developed on NA, three days after incubation at $24^{\circ} \mathrm{C}$. Recovery of Xam from homogenized diseased leaf tissues was also verified on both NA and semi-selective media.

\section{Seed samples}

Samples were obtained from six seed lots belonging to G. hirsutum (three of cv. ITA 90, one of cv. Fabrika and two of cv. Makina) from a 2001 harvest in Mato Grosso of fields producing seeds with angular leaf spot disease (Table 3). The level of disease incidence in these fields was not known. After delinting with concentrated sulfuric acid (Brinkerhoff \& Hunter, 1963) the samples were gently washed three times with tap water, air-dried on filter paper and stored at $5{ }^{\circ} \mathrm{C}$ for further use.

\section{Seed testing assays}

To detect the presence of seed infection in six seed lots, the following methods were used. For all pathogenicity tests, first leaves of 30-35-day-old plants of cvs. Ita 90 and Saturno were inoculated (three plants per cultivar) using a tooth pick method (Cia et al., 1973). Inoculated plants were incubated in a dew chamber for $48 \mathrm{~h}$ and later placed on the greenhouse bench and examined periodically for symptom expression.

Seed washing. Seeds (200 g) were disinfested with $70 \%$ ethyl alcohol for $1 \mathrm{~min}$, immersed $4 \mathrm{~min}$ in sodium hypoclorite (2.5\% of $\mathrm{NaClO})$, followed by three quick 
washings with sterilized water. The disinfested seeds were finally washed in $300 \mathrm{ml}$ of saline water $(0.5 \% \mathrm{NaCl})$ for $24 \mathrm{~h}$ in a mechanical shaker in three replicates. The suspension was filtered through Whatman filter paper No. 1 , centrifuged for $10 \mathrm{~min}$ at $10,000 \mathrm{rpm}$. The pellet was suspended in $5 \mathrm{ml}$ of distilled water and used for pathogenicity tests in the greenhouse;

Direct seed plating. Two thousand seeds were surface disinfected as mentioned earlier for seed washing, but instead of washing again for $24 \mathrm{~h}$, were placed in Petri plates (ten seeds per plate) each containing $15 \mathrm{ml}$ of semiselective medium. Plates were examined periodically seven days after incubation. Within seven-12 days after incubation, typical colonies of Xam growing around the seeds were observed and were tested directly for pathogenicity. The identification of the Xam colonies was based on morphological characteristics like size, colour and consistency which were also confirmed by streaking onto PSA plates. After 12 days no new colonies of Xam were observed.

Growing-on-test. Two thousand seeds of each seed lot were sown in plastic trays $(20 \times 35 \mathrm{~cm})$ containing unsterilized soil in the greenhouse (100 seeds per tray), trays were irrigated once a day and the plants were examined for symptom development 15-35 days after sowing. The average greenhouse temperatures during the experimental period varied between 18 and $26{ }^{\circ} \mathrm{C}$, and the relative humidity between 60 and 85\%. Care was taken to avoid counting plants with secondary infections. For this purpose, plants were examined daily and the infected ones were marked within the first 25-30 days after sowing. Although secondary infection was rare, it was normally identified as a few watersoaked angular spots on the first or second leaves on plants with no other symptoms. Invariably such plants were surrounded by the initially infected plants.

\section{Longevity}

Longevity of Xam in two seed lots was studied by plating 2,000 surface desinfested seeds periodically onto the semi-selective medium using the same procedure as stated for direct seed plating. The coefficient of correlation between the period of seed storage and counting the number of bacterial colonies was evaluated by regression analysis using the "Cricket graph” program, version 1.01 of Macintosh.

\section{Correlation between disease severity in the field and seed infection}

The disease severity levels of angular leaf spot in the field (estimated as the percentage of leaf area infected) were correlated with the level of infection in the seed by plating upto a total of 4,800 seeds of some samples onto the semiselective medium. For this purpose, the disease severity scale of 0-4 for field infection was used, where, $0=$ no disease, $1=$ trace - less than $5 \%$ of the leaf area infected (LAI); $2=$ low ( $<25 \%$ LAI); $3=$ medium $(<50 \%$ LAI); $4=$ severe $(>50 \%$ LAI).

\section{RESULTS}

\section{Plating efficiency}

In the dilution plating, the percentage of Xam recovery on semi-selective agar medium compared well with NA. Colonies were recovered in both media even at a very high dilution indicating the high sensitivity of the semiselective medium to detect the pathogen. (Table 1, Figure 1 ). The colonies of Xam grew faster and were larger on semi-selective medium than on NA. Plating efficiencies (\% mean recovery) on semi-selective medium varied between zero and $187 \%$. Whereas the semi-selective medium favoured good recovery for all the strains of Xanthomonas sp. from cotton, the recovery of one strain of $X$. axonopodis pv. phaseoli (Smith) Dye was zero. The semi-selective medium inhibited the growth of $X$. axonopodis pv. phaseoli during the first three days after incubation (Table 1). Few and very small colonies of this strain developed five days after incubation and hence were not considered for analysis. Amongst the xanthomonads the percentage recovery of $X$. axonopodis pv. citri was one of the highest on semi-selective medium.

Recovery of Xam from homogenised diseased leaf tissues was similar on both NA and semi-selective medium indicating the non-toxicity of the semi-selective medium (Figure 2).

\section{Seed washing}

When suspensions of seed washings were inoculated on susceptible cotton plants, typical disease symptoms were reproduced 12 days after inoculation in seed sample Nos. 5 and 6 in all the three replications (Table 2).

\section{Direct seed plating}

Growth of most of the saprophytic bacteria and fungi was inhibited by the semi-selective agar medium and by the disinfestation of the seeds by alcohol and by sodium hypoclorite. Since the pathogen is internally seed-borne, detection of Xam was not affected by disinfestation as evidenced by some preliminary tests. The addition of gentamycin inhibited the development of most of the fungi and bacteria (Schaad \& Foster, 1985), but it was toxic to Xam. Susbstitution of gentamycin by pencycuron, triadimenol and tolylfluanid, inhibited the development of most of the fungi but at the same time did not affect the development of Xam. Addition of kasugamycin did not improve the medium. It was non toxic to Xam as well as to other saprophytic bacteria. Laboratory tests indicated that some of the saprophytic bacteria associated with the cotton seed were not antagonistic to Xam. The typical colonies of Xam growing around the seed were slightly yellowish, smooth, convex and glistening (Figure 3). The identity of such colonies was always confirmed by streaking onto the PSA medium and by the pathogenicity test in the greenhouse. Out of six seed lots two were free from the bacteria. The semi-selective medium could detect a very small percentage 
TABLE 1 - Number of strains of Xanthomonas spp. on semi-selective agar medium compared to growth on Difco nutrient Agar

\begin{tabular}{llc}
\hline \hline Strain/Pathovar* & Host/State & $\begin{array}{c}\text { Mean recovery } \\
(\mathbf{\%}) * * *\end{array}$ \\
\hline Xan. 13403/malvacearum & Cotton/Mato Grosso & $66 \mathrm{ed}$ \\
Xan. 13355/malvacearum & Cotton/Mato Grosso & $86 \mathrm{ced}$ \\
Xan. 13360/malvacearum & Cotton/Mato Grosso & $100 \mathrm{cbd}$ \\
Xan. 13362/malvacearum & Cotton/Mato Grosso & $87 \mathrm{ced}$ \\
Xan. 13601/malvacearum & Cotton/Mato Grosso & $104 \mathrm{cbd}$ \\
Xan. 13838/malvacearum & Cotton/Mato Grosso & $114 \mathrm{cbd}$ \\
Xan. 13856/malvacearum & Cotton/Mato Grosso & $65 \mathrm{ed}$ \\
Xan. 138058/malvacearum & Cotton/Mato Grosso & $158 \mathrm{cb}$ \\
Xan. 15219/malvacearum & Cotton/Mato Grosso & $103 \mathrm{cbd}$ \\
Xan. 6667/undulosa & Wheat (Triticum aestivum L.)/Paraná & $57 \mathrm{ed}$ \\
Xan. 12917/citri & Citrus (Citrus spp.)/Paraná & $187 \mathrm{a}$ \\
Xan. 3701/phaseoli & Beans (Phaseolus spp.)/Paraná & $0 \mathrm{e}$ \\
Xan. 11370/passiflora & Passionfruit (Passiflora edulis Sims)/Paraná & $56 \mathrm{ed}$ \\
\hline
\end{tabular}

*Xan=Xanthomonas. All strains belong to the culture collection of IAPAR, Londrina;

**(Number of colonies recovered on semi-selective agar medium x 100)/number of colonies on Difco nutrient agar). Calculated from the mean number of colonies per plate in three replications per strain. Columns with the same letter do not differ from each other according to Tukey at $5 \%(p=0.05)$. Xanthomonas strains from passion fruit, citrus, and beans, were collected by Rui Perreira Leite, IAPAR, Londrina, PR.

of infection $(0.05 \%)$, which otherwise was not detected by any other method (Table 2).

\section{Growing-on-test}

The pathogen transmission by growing-on-test in one seed lot was demonstrated under greenhouse conditions (Table 2). Twenty five to 30 days after sowing, typical water soaked translucent angular leaf spot symptoms developed on the first leaves of cv. Makina which in severe cases caused death of the seedling. The identity of the pathogen was confirmed by isolation and by pathogenicity tests in the glasshouse. As mentioned earlier, failure to demonstrate the transmission of the bacteria in other seed lots by growingon-test was possibly due to a relatively low level of seed infection. Besides, an inapropriate temperature and humidity regime during the experimental period may inhibit the development of typical angular leaf spot symptoms, and consequently, a particular seed lot may be wrongly identified as free from Xam. The exact temperature and humidity regime for seed transmission is not well understood.

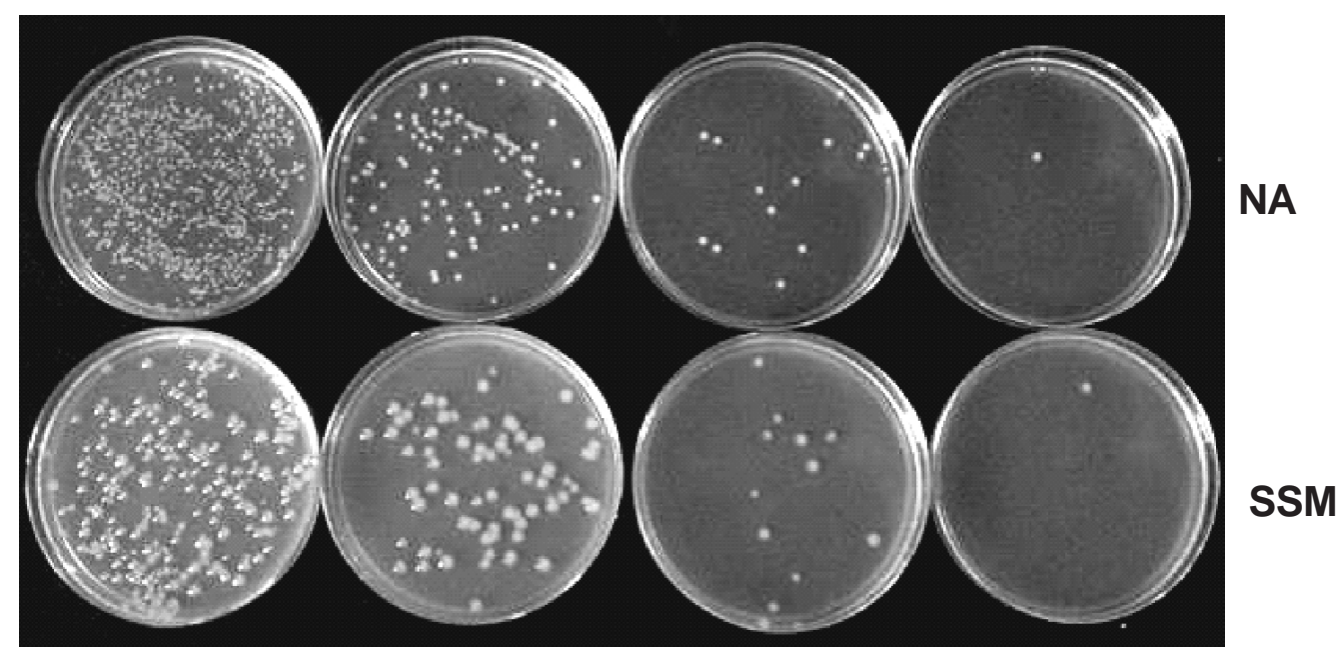

FIG. 1 - Comparison of colony forming units of Xanthomonas axonopodis pv. malvacearum in dilution plating (from left to right $-10^{-4}, 10^{-5}, 10^{-6}, 10^{-7}$ ) between Difco nutrient agar (upper plates) and on semi-selective agar medium (lower plates), three days after incubation. 


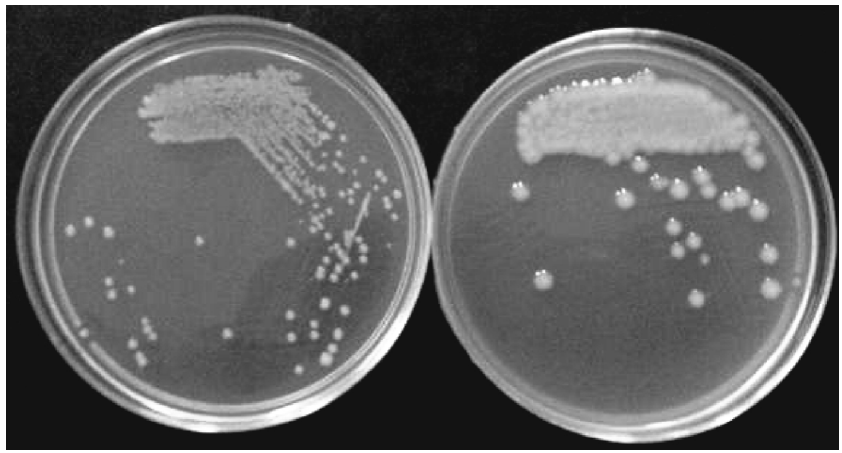

FIG. 2 - Recovery of Xanthomonas axonopodis pv. malvacearum from homogenised diseased cotton (Gossypium hirsutum) leaf tissues on Difco nutrient agar (left) and on semi-selective agar medium (right), three days after isolation.

\section{Longevity}

By using the semi-selective medium it was possible to study the longevity of Xam in two naturally infected cotton seed lots. The viability of bacteria started declining gradually 12 months after harvest and reached the lowest level after 23-26 months of storage (Table 3). The reduction in the level of seed infection was inversely proportional to the increase in storage period. For the seed lots No. 5 and 6, the coefficient of correlation (r) was 0.890 and 0.975 , respectively. Unfortunately, there is no information regarding whether there was a decline or not in the level of seed infection during the first 12 months after harvest, since the semi-selective medium was developed after this period. The results showed that the bacteria can survive in the infected seed for a period of at least 28 months, especially when the seed is stored at $5{ }^{\circ} \mathrm{C}$. The longevity of Xam in dried leaves preserved under laboratory conditions for seven years and in the seed for 56 months was demonstrated by Schnathorst (1964) and Hunter \& Brinkerhoff (1964), respectively. It is also known that $X$. campestris pv. undulosa

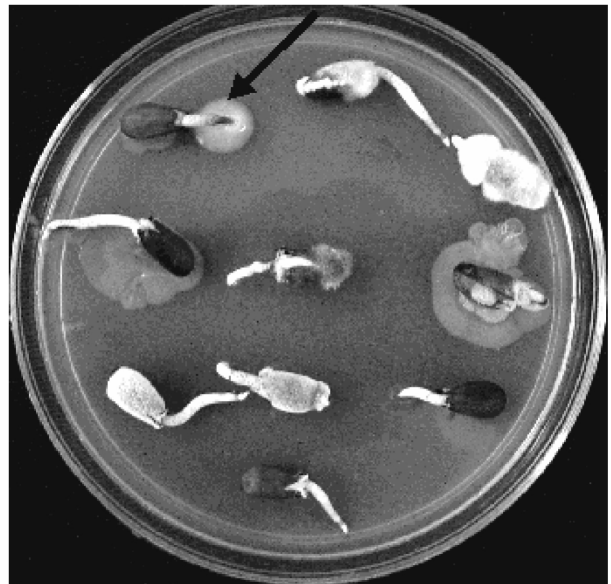

FIG. 3 - Typical colony growth of Xanthomonas axonopodis pv. malvacearum indicated by an arrow, recovered on semi-selective agar medium from naturally infected cotton (Gossypium hirsutum) seed, eight days after incubation at $24^{\circ} \mathrm{C}$.

Hagb of wheat, for example, can survive in the infected seed for a period of over four years (Mehta, 1990; Mehta \& Bassoi, 1993; Bragaard et al., 1993). Further research is needed to verify the longevity of Xam in the infected seed at the normal storage conditions (about $24^{\circ} \mathrm{C}$ ) commercially practiced in Brazil.

\section{Correlation between disease severity in the field and seed infection}

Results indicate that the disease severity levels of angular leaf spot in the field did not always correlated with the level of infection in the seed (Table 4).

\section{DISCUSSION}

In general, the semi-selective medium showed good plating efficiency for the strains of $X$. axonopodis $\mathrm{pv}$.

TABLE 2 - Detection of Xanthomonas axonopodis pv. malvacearum (Xam) in six naturally infected commercial cotton (Gossypium hirsutum) seed lots by three different methods

\begin{tabular}{lllcc}
\hline & \multicolumn{1}{c}{$\begin{array}{c}\text { Origin } \\
\text { Seed lot and cotton cultivar }\end{array}$} & \multicolumn{2}{c}{ Seed infected with Xam } \\
\cline { 3 - 4 } & Location/State/Year & Method of detect ion* \\
\cline { 3 - 5 } & & Seed washing & $\begin{array}{c}\text { Seed plating on semi- } \\
\text { selective medium** }\end{array}$ & Growing on-Test \\
\hline Fabrika & Rondonó polis,MT/2001 & Negative & $4(0.20 \%)$ & 0 \\
Ita 90 A & Serra de Petrolina, MT/2001 & Negative & 0 & 0 \\
Makina & Rondonó polis, MT/2001 & Negative & $1(0.05 \%)$ & 0 \\
Ita 90 B (treated with unknown fungicide) & Rondonó polis (Salles), MT/2001 & Negative & 0 & No data due to \\
ITA 90 C & Itiquira, MT/2001 & Positive*** & $21(1.05 \%)$ & short of seed \\
Makina & Costa Rica, MT/2001 & Positive*** & $20(1.00 \%)$ & $31(1.55 \%)$ \\
\hline
\end{tabular}

*See text for details of the three methods of detection.

**Number (percentage of infected seed with Xam).

***After seed washing the pellet containing Xam produced typical symptoms of the disease 12 days after inoculation. Delinting was done using concentrated sulphuric acid (Brinkerhoff \& Hunter, 1963). 
TABLE 3 - Longevity of Xanthomonas axonopodis pv. malvacearum (Xam) in naturally infected cotton (Gossypium hirsutum) seeds stored at $5^{\circ} \mathrm{C}$ soon after harvest

\begin{tabular}{|c|c|c|}
\hline \multirow{2}{*}{$\begin{array}{l}\text { Date of seed analysis/ } \\
\text { recovered on } \\
\text { months after harvest }\end{array}$} & \multicolumn{2}{|c|}{$\begin{array}{l}\text { Number of seeds which anabled the recovery of Xam } \\
\text { on semi - selective medium from two seed lots* }\end{array}$} \\
\hline & Seed lot - cv. Ita 90 & Seed lot - cv. Makina \\
\hline August 5, 2002/12 & 21 & 20 \\
\hline October, $7,2002 / 14$ & - & 13 \\
\hline February $24,2002 / 18$ & - & 11 \\
\hline March 19, 2003/19 & - & 6 \\
\hline April 2, 2003/20 & 5 & - \\
\hline May $12,2003 / 21$ & 2 & - \\
\hline Ju ne $5,2003 / 22$ & - & 1 \\
\hline July $5,2003 / 23$ & 2 & 0 \\
\hline October $1,2003 / 26$ & 4 & - (Short of seed) \\
\hline December 5, 2003/28 & 4 & - (Short of seed) \\
\hline
\end{tabular}

*Seed samples originated from fields with angular leaf spot from the State of Mato Grosso, and soon after harvest in July, 2001, stored at $5{ }^{\circ} \mathrm{C}$. For each analysis 2,000 surface sterilised seeds were placed on Petri dishes containing semi-selective medium. Typical Xam colonies were observed eight-ten days after incubation at $24^{\circ} \mathrm{C}$ in dark. (-) indicates lack of data. The coefficient of correlation (r) between the increase in storage period and the number of colonies of Xam, for cv. Ita 90 and for cv. Makina was 0.890 and 0.975 respectively.

TABLE 4 - Relationship between angular leaf spot severity in the field and the percentage of infected cotton (Gossypium hirsutum) seeds with Xanthomonas axonopodis pv. malvacearum (Xam) determined by using the semi-selective medium

\begin{tabular}{lcccc}
\hline \hline $\begin{array}{l}\text { Cotton } \\
\text { Cultivar* }\end{array}$ & $\begin{array}{c}\text { Disease } \\
\text { severity } \\
\text { in the field** }\end{array}$ & $\begin{array}{c}\text { No. of seeds } \\
\text { analysed using } \\
\text { semi - selective } \\
\text { medium*** }\end{array}$ & $\begin{array}{c}\text { Average No. } \\
\text { of infected } \\
\text { seeds }\end{array}$ & $\begin{array}{c}\text { \% } \\
\text { infected } \\
\text { seed }\end{array}$ \\
\hline Breder's line & 3 & 4,800 & 0 & 0 \\
Saturno & 3 & 4,800 & 9 & 0.38 \\
ITA 90 -D & 2 & 4,800 & 0 & 0 \\
ITA 90 -E & 3 & 4,800 & 1 & 0.04 \\
ITA 90 -F & 4 & 4,800 & 5 & 0.21 \\
Alcapi & 0 & 800 & 0 & 0 \\
Alcapi & 3 & 800 & 4 & 0.5 \\
Delta Opal & 0 & 800 & 0 & 0 \\
STO 474 & 1 & 800 & 0 & 0 \\
Saturno & 2 & 800 & 0 & 0 \\
\hline
\end{tabular}

*Seed samples originated from different fields or without angular leaf spot from the State of Mato Grosso, with the exception of the Breeder's line which was from the State of Paraná. Soon after harvest in June, 2003, the seeds were disinfested and were analised using semi-selective medium. Typical Xam colonies growing around the infected seeds were observed 812 days after incubation at $24^{\circ} \mathrm{C}$ in dark.

**Disease severity scale of $0-4$ for field infection was used, where, $0=$ no disease, $1=$ trace - less than $5 \%$ of the leaf area infected (LAI); $2=$ low $(<25 \% \mathrm{LAI})$; $3=$ medium $(<50 \% \mathrm{LAI}) ; 4=$ severe $(>50 \% \mathrm{LAI})$.

$* * *$ For the first five seed lots 4,800 seeds were analysed in two replications of 2,400 seeds each. Due to the limited seed of the rest of the seed lots, only 800 seeds were analysed.

malvacearum as compared to other xanthomonads. Among the three detection methods tested, the semi-selective medium was found to be the most reliable for quantitative assays. The identity of Xam colonies appearing around the infected seeds on the semi-selective agar medium was confirmed by pathogenicity tests, which are considered desirable since some of the colonies of Xam may loose their pathogenicity, or else they may still be confused with some of the yellow pigmented saprophytic bacteria. Alternatively, identification of Xam colonies may also be confirmed by morphological characteristics by streaking onto the PSA medium and comparing with the type culture colonies of Xam. Our experience shows that the colonies, once confirmed by streaking onto the PSA medium, were always pathogenic to cotton. Pathogenicity tests may be dispensable if identification is coupled with molecular analysis using a highly specific DNA probe. Nonetheless, the semi-selective agar medium presented here is practical and can be used for screening large number of seed samples. The medium can also be used for quarantine purposes.

Normally, the percentage of seed infection by Xam is very low. A relatively low percentage of seed infection, however, would be sufficient to create a severe epidemic of the disease under favourable field conditions (Brinkerhoff \& Hunter, 1963). Considering the low percentage of seed infection and the possible establishment of a zero tolerance level for seed infection by the Ministry of Agriculture of Brazil, we suggest that 2,000 seeds per seed lot should be examined.

Although the pathogen can survive in seed and in volunteer cotton plants, no secondary or collateral hosts are known. The bacterium like most xanthomonads, is sensitive to drying and excessive heat, and is rapidly destroyed when 
crop residue is buried soon after the cotton harvest (Arnold \& Arnold, 1961; Brinkerhoff \& Fink, 1964; Mehta, 1993). Such conditions prevail especially in the State of Mato Grosso, and thus reduce the possibility of survival of the pathogen in infected cotton plant residue. Although longevity and the role of inoculum present in crop residue under Brazilian conditions are not well studied, our results show that the seed could be an important source of primary infection of angular leaf spot in Brazil.

The disease severity levels of angular leaf spot in the field were not always correlated with the level of infection in the seed, even when the test was repeated and a total of 4,800 seeds of some samples were plated onto the semiselective medium (Table 4). Similar results were obtained by Mohan \& Schaad (1987) while working with bean blight bacteria. Because of the limited sample size, only 800 seeds were tested of some seed lots. Correlation between the level of field infestation and the level of seed infection would depend on the climatic conditions between the boll formation and boll opening. Future research using a large number of seed samples is considered essential to improve our understanding of the correlation between field infection and seed infection. Nonetheless, results indicate that the seed production fields infested with angular leaf spot disease can not be simply condemned. To the contrary, it would be worthwhile to adopt a zero tolerance level for seed infection but not for field infestation, especially now when the semiselective medium has been made available. Besides, field inspections are not always very reliable and nor foolproof (Mohan \& Schaad, 1987).

This is the first report of a semi-selective agar medium to detect the presence of Xam in commercial cotton seed. The development of such a medium would certainly provoke furture investigations into the establishment of appropriate methods designed to erradicate the pathogen from the cotton seed. The use of semi-selective medium would permit planting of only the healthy seeds for commercial cultivation. Along with healthy seeds the use of resistant cultivars would effectively control the angular spot disease of cotton.

\section{ACKNOWLEDGMENTS}

The present research was sponsored by Facual Fundação Apoio a Cultura de Algodão, MT, Brazil. Thanks are due to Paulo Aguiar, Fabiano V. Sequeri and Tatiane S. Zambosi for supplying part of the seed material from the State of Mato Grosso, and for technical assistance provided by J.A. Oliveira and Edna Marcolini.

\section{LITERATURE CITED}

ARNOLD, M.H. \& ARNOLD, K.M. Bacterial blight of cotton:trash-borne infection. Empire Cotton Growing Review 38:258-270. 1961.
BAIN, D.C. Effect of sulphuric-acid treatment on fungi and bacteria present on cotton seed from diseased bolls. Phytopathology 29:879-884. 1939.

BRAGAARD, C., MEHTA, Y.R. \& MARAITE, H. Serodiagnostic assays vs. the routine techniques to detect Xanthomonas campestris pv. undulosa in wheat seeds. Fitopatologia Brasileira 18:42-50. 1993.

BRINKERHOFF, L.A. \& FINK, G.B. Survival and infectivity of Xanthomonas malvacearum in cotton plant debris and soil. Phytopathology 54:1198-1201. 1964.

BRINKERHOFF, L.A. \& HUNTER, R.E. Internally infected seed as a source of inoculum for the primary cycle of bacterial blight of cotton. Phytopathology 53:1397-1401. 1963.

CIA, E., BALMER, E., FERRAZ, C.A.M., GRIDI-PAPP, I.L. \& PARADELA FILHO, O. Variabilidade de Xanthomonas malvacearum (E.F. Smith) Dowson, no Estado de São Paulo. Anais da Escola Superior da Agricultura “Luiz de Queiroz” 30:457-463. 1973.

CLAFLIN, L.E., VIDABER, A.K. \& SASSER, M. MXP, a semiselective medium for Xanthomonas campestris pv. phaseoli. Phytopathology 77:730-734. 1987.

GOULART, A.C.P. \& FERRAZ, D.M. Efeito do tratamento de sementes de algodão com fungicidas no controle do tombamento de plântulas causado por Rhizoctonia solani. Anais, $3^{\circ}$ Congresso Brasileiro de Algodão, Campo Grande, MS, 2001. pp.560-563.

HALFON-MEIRI, A. \& VOLCANI, Z. A combined method for detecting Colletotrichum gossypii and Xanthomonas malvacearum in cotton seed. Seed Science \& Technology 5:129-139. 1977.

HUNTER, R.E. \& BRINKERHOFF, L. A. Longivity of Xanthomonas malvacearum on and in cotton seed. Phytopathology 54:617. 1964.

KADO, C.I. \& HESKETT, M.G. Selective media for isolation of Agrobacterium, Corynebacterium, Erwinia, Pseudomonas and Xanthomonas. Phytopathology 60:969-976. 1970.

MEHTA, Y.R. Management of Xanthomonas campestris pv. undulosa through cereal seed testing. Seed Science and Technology, 18:467-476. 1990.

MEHTA, Y.R. Manejo integrado de enfermedades del trigo. Imprenta Landivar, Santa Cruz de la Sierra, Bolivia. 1993.

MEHTA, Y.R. \& BASSOI, M.C. Guazatine Plus as a seed treatment bactericide to eradicate Xanthomonas campestris pv. undulosa from wheat seeds. Seed Science and Technology 21:924. 1993.

MEHTA, Y.R. \& BOLOGNINI, V. Meio semi-seletivo para detectar a presença de Xanthomonas axonopodis pv. malvacearum nas sementes do algodoeiro. Fitopatologia Brasileira 28:240. 2003 (Abstract).

MOHAN, S.K. A survey of methods for detection of Xanthomonas campestris pv. malvacearum in cotton seed. Seed Science and Technology 11:569-571. 1983a.

MOHAN, S.K. Seed transmission and epidemiology of Xanthomonas campestris pv. malvacearum. Seed Science and Technology 11:859-865. 1983b.

MOHAN, S.K. \& SCHAAD, N.W. An improved agar plating assay for detecting Pseudomonas syringae pv. syringae and $P$. s. pv. phaseolicola in contaminated bean seed. Phytopathology 77:13901395. 1987. 
RANDHAWA, R. S. \& SCHAAD, N.W. Selective isolation of Xanthomonas campestris pv. campestris from crucifer seeds. Phytopathology 74:268-272. 1984.

SCHAAD, N.W. \& FORSTER, R.L. A semi-selective agar medium for isolating Xanthomonas campestris pv. translucens from wheat seeds. Phytopathology 75:260-263. 1985.
SCHNATHORST, W.C. Longivity of Xanthomonas malvacearum in dried cotton plants and its significance in dissemination of the pathogen on seed. Phytopathology 54:1009-1011. 1964.

TARR, A.S.J. Seed treatment against blackarm disease of cotton in the Sudan. V. Results with seed carrying light and moderate infection. Empire Cotton Growing Review 38:30-35. 1961. 